Abstracta Iranica Abstranica

Revue bibliographique pour le domaine irano-aryen

Volume 40-41 | 2019

Comptes rendus des publications de 2017-2018

\title{
Antonio Panaino. “On Iran's Role in the Transmission of Ancient Astral Science and the Ramifications thereof"
}

Alessia Zubani

\section{(2) OpenEdition}

Journals

Édition électronique

URL : http://journals.openedition.org/abstractairanica/51026

DOI : 10.4000/abstractairanica. 51026

ISBN : 1961-960X

ISSN : 1961-960X

Éditeur :

CNRS (UMR 7528 Mondes iraniens et indiens), Éditions de l'IFRI

Référence électronique

Alessia Zubani, « Antonio Panaino. "On Iran's Role in the Transmission of Ancient Astral Science and

the Ramifications thereof" », Abstracta Iranica [En ligne], Volume 40-41 | 2019, document 6, mis en ligne le 30 décembre 2019, consulté le 21 avril 2021. URL : http://journals.openedition.org/

abstractairanica/51026 ; DOI : https://doi.org/10.4000/abstractairanica.51026

Ce document a été généré automatiquement le 21 avril 2021.

Tous droits réservés 


\title{
Antonio Panaino. “On Iran's Role in the Transmission of Ancient Astral Science and the Ramifications thereof"
}

\author{
Alessia Zubani
}

\section{RÉFÉRENCE}

Antonio Panaino. "On Iran's Role in the Transmission of Ancient Astral Science and the Ramifications thereof" in David Brown, with contributions by Jonathan Ben-Dov, Harry Falk, Geoffrey Lloyd, Raymond Mercier, Antonio Panaino, Joachim Quack, Alexandra Von Lieven, Michio Yano. The Interactions of Ancient Astral Science. Bremen: Hempen Verlag, 2018, p. 456-514

L'étude s'insère dans un projet ambitieux dirigé par D. Brown, visant à mettre en relief le phénomène d'interactions des savoirs astronomiques et astrologiques dans l'espace eurasiatique ancien (jusqu'au 7e s.). À cette fin, l'A. explore la contribution essentielle du monde iranien, souvent sous-estimée, voire ignorée. Les empires achéménide et sassanide ont manifestement joué un rôle interculturel décisif dans l'histoire des sciences anciennes, qu'on ne peut se permettre de passer sous silence. En parcourant les thèmes fondamentaux des sciences astrales iraniennes (fonction astronomique des divinités, telles que Tištriia ou l'étoile Sirius; les statuts des étoiles; la démonisation des planètes), il est possible de reconnaître et d'analyser les dynamiques de la circulation des doctrines astrales entre l'Iran préislamique et ses principaux interlocuteurs. 


\section{AUTEURS}

\section{ALESSIA ZUBANI}

Doctorante EPHE, Mondes iranien et indien, Paris 